Nenad Tasić

Filozofski fakultet, Beograd

ntasic@f.bg.ac.rs

Momir Vukadinović

Institut Jaroslav Černi, Beograd

Aleksandar Kapuran

Arheološki institut, Beograd

UDK 902.3:550.8(497.11)"2000"

Izvorni naučni članak

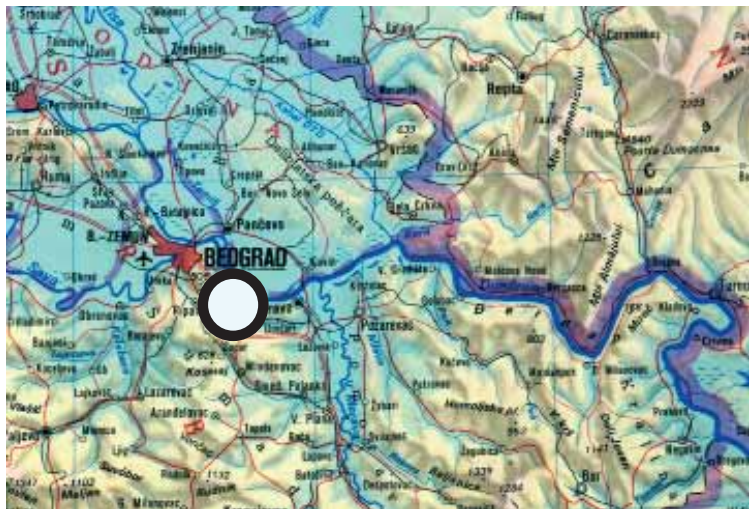

Belo brdo, Vinča, Srbija

LAT 44 45' 34" / LONG 20 37'29"

\title{
KOMPARATIVNA ARHEOLOŠKA I GEOFIZIČKA ISPITIVANJA NA LOKALITETU VINČA - BELO BRDO METODOM GEOELEKTRIČNOG SKENIRANJA
}

\begin{abstract}
APSTRAKT
U ovom radu predstavljen je metod geoelektrične tomografije obavljen na višeslojnom arheološkom nalazištu Belo Brdo u Vinči 2000. godine. Primenjeni geofizički metod izabran je da bi se dobila što bolja rezolucija pri detekciji podzemnih struktura. Ovaj poduhvat je od značaja za arheološka istraživanja, s obzirom da je jedan od geoelektričnih profila bio postavljen neposredno uz arheološki profil, što je omogućilo direktno upoređivanje dobijenih rezultata geoelektričkog skeniranja i rezultata arheoloških iskopavanja. Osim međusobne provere, ova merenja su od koristi za početak atribucije pojedinih vrsta arheoloških slojeva pojedinim specifičnim otpornostima.
\end{abstract}

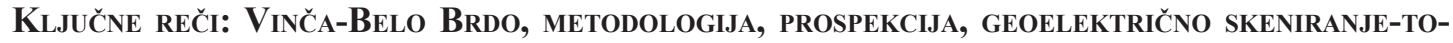
MOGRAFIJA, ELEKTRIČNA OTPORNOST, NEOLIT, ENEOLIT, BRONZANO DOBA

\section{UVOD}

Istraživanja na nalazištu Vinča-Belo Brdo obnovljena su u jesen 1998. godine upravo na devedesetogodišnjicu prvih istraživanja profesora Miloja Vasića. Njegova iskopavanja su decenijama predstavljala sam vrh arheološke metodologije. Arheološka dokumentacija sa pomenutih iskopavanja, koju je profesor Miloje Vasić ostavio za sobom i danas predstavlja izuzetno važan izvor za proučavanje vinčanske kulture. Četiri knjige Praistorijska Vinča, iako po pitanju hronologije dobrim delom prevaziđene, još uvek su uzor za objavljivanje rezultata arheoloških iskopavanja. Ovakav povod i delo koje je za sobom ostavio pro- fesor Vasić, obavezivale su i potonje istraživače da pokušaju da eponimnom nalazištu vinčanske kulture vrate mesto koje mu pripada.

Odlučili smo se da prilikom novih iskopavanja uvedemo multidisciplinarnost i donekle promenimo uobičajeni ritam istraživanja. Želja nam je bila da što potpunije sagledamo pojedine nepokretne objekte, istražujući detalje koji u vreme Vasićevih radova nisu mogli biti konstatovani u pokušaju da obezbedimo što bolji kontekst za pokretni arheološki materijal. Planirano je sprovođenje različitih fizičko-hemijskih analiza koje bi mogle da pomognu u rekonstrukciji uslova života tokom poznog neolita (stanište, ishrana, itd.), ali takođe da nam pokažu međusobni 
odnos objekata. Upravo jedna od novih tehnika metodologije istraživanja je geofizička prospekcija, odnosno snimanje nalazišta putem merenja električnog rezistiviteta čijim rezultatima je i posvećen ovaj rad.

Istraživanja geoelektričnog rezistiviteta na arheološkim nalazištima dole opisanom metodologijom novina je u našoj arheologiji. Stoga smo smatrali svrsishodnim vršenje uporednih geofizičkih i arheoloških istraživanja u cilju provere i atribucije vrednosti dobijenih ispitivanjem električnog otpora. Drugim rečima, pokušali smo da slojeve koji su dobijeni softverskom interpretacijom rezultata električne detekcije preklopimo sa poznatim profilom sondi, istraženih arheološkim iskopavanjima.

Primena metoda geofizičke prospekcije u arheologiji započeta je šezdesetih godina dvadesetog veka. Cilj uvođenja geofizike u arheološku praksu bio je da pomogne pri pronalaženju ostataka kulturnih slojeva, zidova, grobnica i ostalih objekata. Prva ispitivanja bila su uglavnom eksperimentalna, a prve metode korišćene na našim prostorima su geomagnetske i geoelektrične. U vreme tih, pionirskih pokušaja, geofizički instrumenti su bili dosta glomazni i nepraktični, a postupak obrade snimljenih podataka na terenu bio je dug i zamoran zbog komplikovanog matematičkog aparata kojim su geofizičari morali da se koriste. Te i neke druge okolnosti otežavale su širu primenu ovih metoda u arheologiji.

Nagli razvoj računarske tehnologije u poslednjih desetak godina omogućio je da se veličine terenskih geofizičkih instrumenata smanje na dimenzije koje su ranije bile nezamislive. Pojavom personalnog računara obrada podataka svela se na nekoliko sekundi u odnosu na raniji radni postupak od nekoliko nedelja. Zatim, uvođenje posebnih kompjuterskih programa, specijalističkog softvera, omogućilo je da se rezultati merenja predstave dvodimenzionalno ili trodimenzionalno, što je osnova za ozbiljan istraživački rad i efikasnu saradnju geologa-geofizičara sa drugim naukama.

Ovaj interdisciplinarni poduhvat arheologa i geologa je samo nastavak duge zajedničke istorije naših nauka. Od prvih arheoloških tekstova, koji su gotovo po pravilu izlazili iz pera ondašnjih geologa, kao i arheologiji pozajmljenog stratigrafskog metoda, pa sve do zajedničkog rada na detekciji arheoloških ostataka u novije vreme, ova tradicija i dalje daje samo pozitivne rezultate.

Primenom metoda merenja specifičnog električnog otpora pokušali smo da steknemo uvid u još uvek neistražene dubine arheološkog nalazišta Belo Brdo u Vinči. Izmereni profili, uklopljeni su u geodetsku mrežu arheološkog nalazišta i postavljeni tako da se odmah, klasičnim arheološkim iskopavanjima mogla proveriti preciznost metoda i poslati povratna informacija da bi se napravila ,atribucija” pojedinih vrsta zemljišta, odnosno sastava tla, kao i arheoloških objekata u odnosu na vrednosti električne otpornosti dobijene merenjem. Namera nam je bila da svaki sloj, nastao bilo kao rezultat ljudskog delovanja (pečena zemlja, gar, stambeni objekti, otpadne jame), ili kao posledica prirodnih činilaca (aluvijalni ili eolski nanosi), dobije vrednosti specifične električne otpornosti. Na taj način bi, posle narednih merenja, bilo moguće sagledati prostiranje pojedinih slojeva i uskladiti strategiju i tempo arheoloških iskopavanja. Planirano je snimanje još nekoliko profila, koji bi rekonstruisali prvobitnu topografiju terena i dali odgovor na pitanje postoji li palisadno utvrđenje oko jednog od vinčanskih naselja. Novim merenjima bi se, takođe, mogle utvrditi granice naseljavanja u pojedinim fazama vinčanske kulture.

Na lokalitetu Belo Brdo kod Vinče u okolini Beograda, u periodu od 1999 do 2000 godine, izvršena su prvo probna geofizička ispitivanja metodom vertikalnog geoelektričnog sondiranja, a zatim su 2001 godine izvršena ispitivanja na četiri profila metodom geoelektričnog skeniranja ili geoelektrične tomografije.

\section{METODA GEOELEKTRIČNOG SKENIRANJA ILI GEOELEKTRIČNE TOMOGRAFIJE}

Pod geoelektričnim skeniranjem ili tomografijom podrazumeva se istraživanje raspodele električne otpornosti geoloških sredina u funkciji dubine ispod površine ispitivanog terena. Pošto se pretpostavlja da je podzemlje izgrađeno od različitih geoloških slojeva, koji imaju razne debljine i zauzimju različite položaje, poznato je da svaki od tih slojeva ima svoju specifičnu električnu otpornost. Da bi izmerili specifičnu električnu otpornost - SEO, svakog od tih slojeva ili sredina, 
sprovodimo niz terenskih postupaka.

U tlo se uvode jake struje iz portabilnih galvanskih izvora koje teku kroz razne slojeve različitom gustinom strujnih linija. Kako se izazivanje strujnih tokova vrši po površini terena, tako se isto po površini mere i efekti koji su prouzrokovani njihovim uspostavljanjem. Ti efekti su u stvari potencijalne razlike koje se mere na mernim tačkama. Elektrode kojima uvodimo struju u tlo nazivamo strujnim, a elektrode kojima merimo izazvane potencijale nazivamo potencijalnim. $\mathrm{Na}$ taj način, od izmerenih vrednosti struja i razlike potencijala, po Omovom zakonu, poznatom iz elektrotehnike, sračunavamo električnu otpornost. Da bi došli do podataka o broju prisutnih slojeva i njihovih električnih otpornosti, o geometriji ili građi podzemlja, dobijeni podaci se analiziraju specijalnim postupkom takozvanom interpretacijom računarskim programom u varijanti dvodimenzionalnog modela (2 D).

Izmereni podaci na terenu se zapisuju i obrađuju u programu za izračunavanje električne specifične otpornosti, zatim se ubacuju u drugi program za formiranje »import« fajla i na kraju se koristi treći program za finalnu interpretaciju tako da je obrada podataka na personalnom računaru generalno podeljena $u$ tri faze.

Terenska ispitivanja metodom geoelektričnog skeniranja izvode se na taj način što se mesingane ili bakarne elektrode u linijskom nizu postave po površini terena iznad one oblasti koju želimo da istražimo. Biranje mernog dispozitiva i uključivanje pojedinih elektrodnih kombinacija (za odgovarajuće dubinske nivoe), vrši se preko specijalnog preklopnika, preko koga je višežilnim kablom povezan kompletan linijski raspored elektroda. Pri tome, elektrodama se prema sistemu merenja menjaju uloge, odnosno svaka može biti ili strujna ili potencijalna. Elektrode su posebnim filterom međusobno odvojene, obezbeđena je zaštita od telurskih struja, a sopstveni potencijal između aktiviranih potencijalnih elektroda se manuelno ili automatski poništava. Korišćeni linijski raspored ima 51 elektrodu, a veza sa višežilnim kablom se obavlja pomoću štipaljki. Na prvom dubinskom nivou ispitivanja, rastojanje elektroda je najmanje $\mathrm{i}$ jednako je minimalnom rastojanju elektroda $\mathrm{u}$ dispozitivu (a).

Po izvođenju prvog merenja, kada su aktivirane prve četiri elektrode 1, 2, 3 i 4, kako je to naznačeno na principijelnoj šemi, aktiviraju se elektrode 2, 3, 4 i 5, pri čemu elektrode 2 i 5 imaju ulogu strujnih, a 3 i 4 potencijalnih. Merene vrednosti prividne specifične električne otpornosti se pripisuju određenoj tačci trenutno aktivnog dispozitiva, što je naznačeno tačkicama. Postupak se na sličan način ponavlja, dok se ne izvrše sva merenja na prvom dubinskom nivou ispitivanja. Merenja na drugom dubinskom nivou započinju aktiviranjem elektroda 1, 3, 5 i 7, koje su na međusobnom rastojanju $2 \mathrm{a}$, čime se postiže veći dubinski zahvat ispitivanja. Korak ispitivanja na svim nivoima jednak je minimalnom rastojanju elektroda (a), tako da se kod sledećeg merenja na drugom nivou aktiviraju elektrode 2, 4, 6 i 8, gde elektrode 2 i 8 imaju ulogu strujnih, a 4 i 6 potencijalnih elektroda. $\mathrm{Na}$ taj način se potpuno šematski isto i automatski vrši merenje na svim dubinskim nivoima.

Zbog povećanja dimenzija mernog dispozitiva sa povećanjem dubine ostalih nivoa ispitivanja, smanjuje se broj merenih podataka specifične električne otpornosti, SEO, kako se vidi na datoj šemi za primenjeni Venerov dispozitiv. Zbog toga prostorna pozicija prikupljenih podataka ima trapezoidnu formu. Ovako organizovanim merenjima, koja su delimično ili potpuno automatizovana, ostvaruje se dovoljna gustina podataka za utvrđivanje bočnih promena specifične električne otpornosti, a istovremeno i dovoljan maksimalni dubinski zahvat ispitivanja, čime se objedinjavaju osobine geoelektričnog sondiranja i geoelektričnog kartiranja. Sekcije prividne SEO odražavaju raspodelu specifičnih električnih otpornosti i geometriju ispitivanog poluprostora, što omogućava izvođenje 2 D interpretacije.

Ispitivanja geoelektričnim skeniranjem moguće je izvesti primenom različitih rasporeda elektroda, aktiviranjem odgovarajućih elektroda u linijskom nizu više elektroda. Neki od najčešće upotrebljavanih dispozitiva prikazani su na slici 2 .

Rezultati merenja geoelektričnim skeniranjem prikazani su u vidu sekcija električnih otpornosti koje su predstavljene odgovarajućim slikama u boji. Svaka od zastupljenih boja ima odgovarajuću vrednost električne otpornosti, što u praksi znači da su posredno identifikovane geološke sredine i njihova prostorna pozicija (debljina, dubina zaleganja itd.). Zbog metodološkog, odnosno geoelektričnog pristupa rešavanju ove 


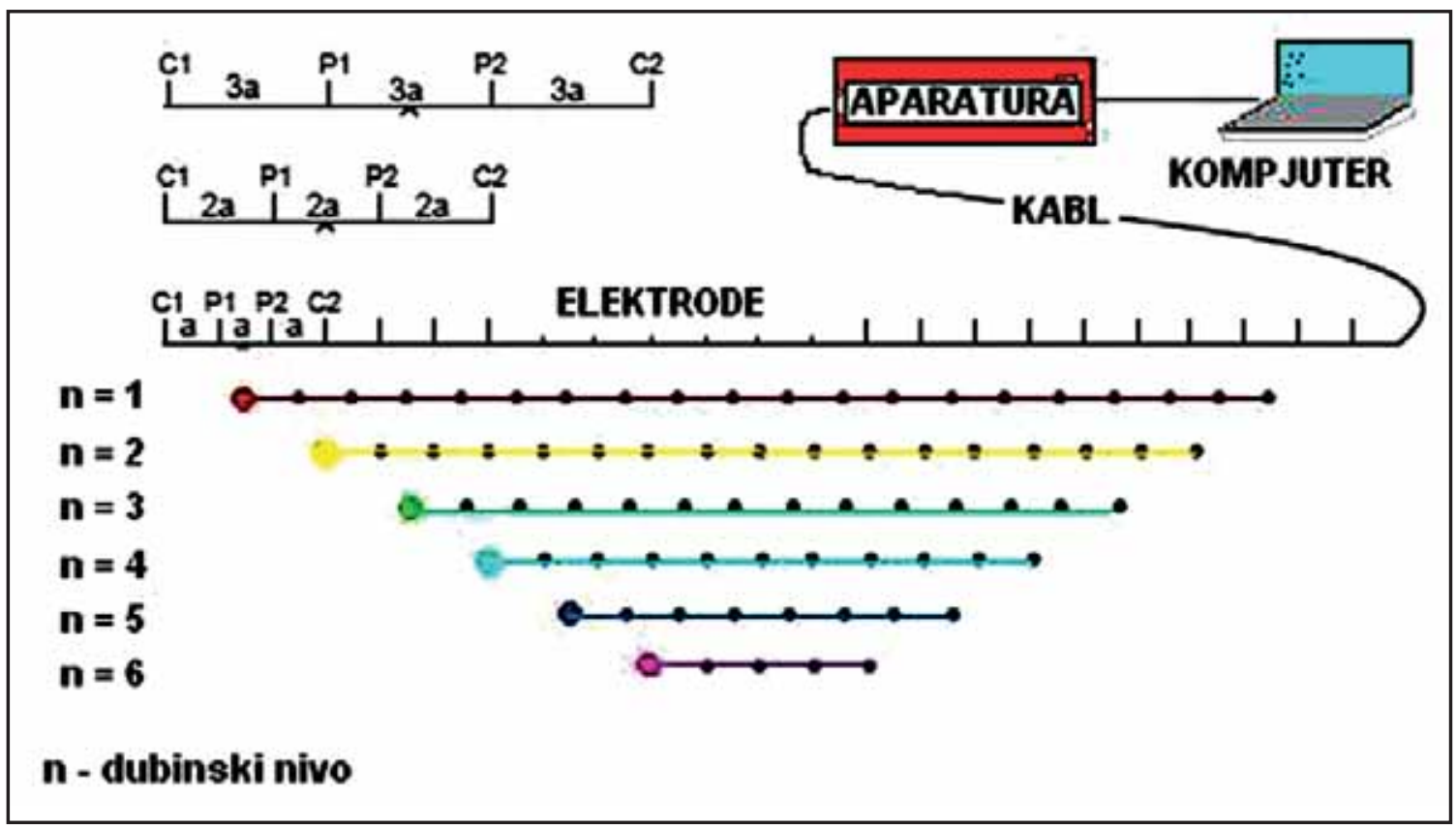

Slika 1. Principijelna šema veza geoelektričnog skeniranja

problematike, izdvojene sredine, po parametru specifične električne otpornosti, nazivamo geoelektričnim sredinama, a rezultate skeniranja predstavljamo geoelektričnim presecima.

Obrada prikupljenih terenskih podataka izvršena je na personalnom računaru, Pentium II, a program za obradu podataka skeniranja je RES2 Dinv.

\section{REZULTATI GEOELEKTRIČNOG SKENIRANJA ILI TOMOGRAFIJE NA LOKALITETU BELO BRDO}

Na lokalitetu Belo Brdo, metodom skeniranja dobijena su četiri vertikalna geoelektrična preseka sa oznakama VGF-1, 2, 3 i 4.

Preseci VGF-2 i VGF-3 su dugački po $50 \mathrm{~m}$, a dubinski zahvat je $8 \mathrm{~m}$. Preseci VGF-1

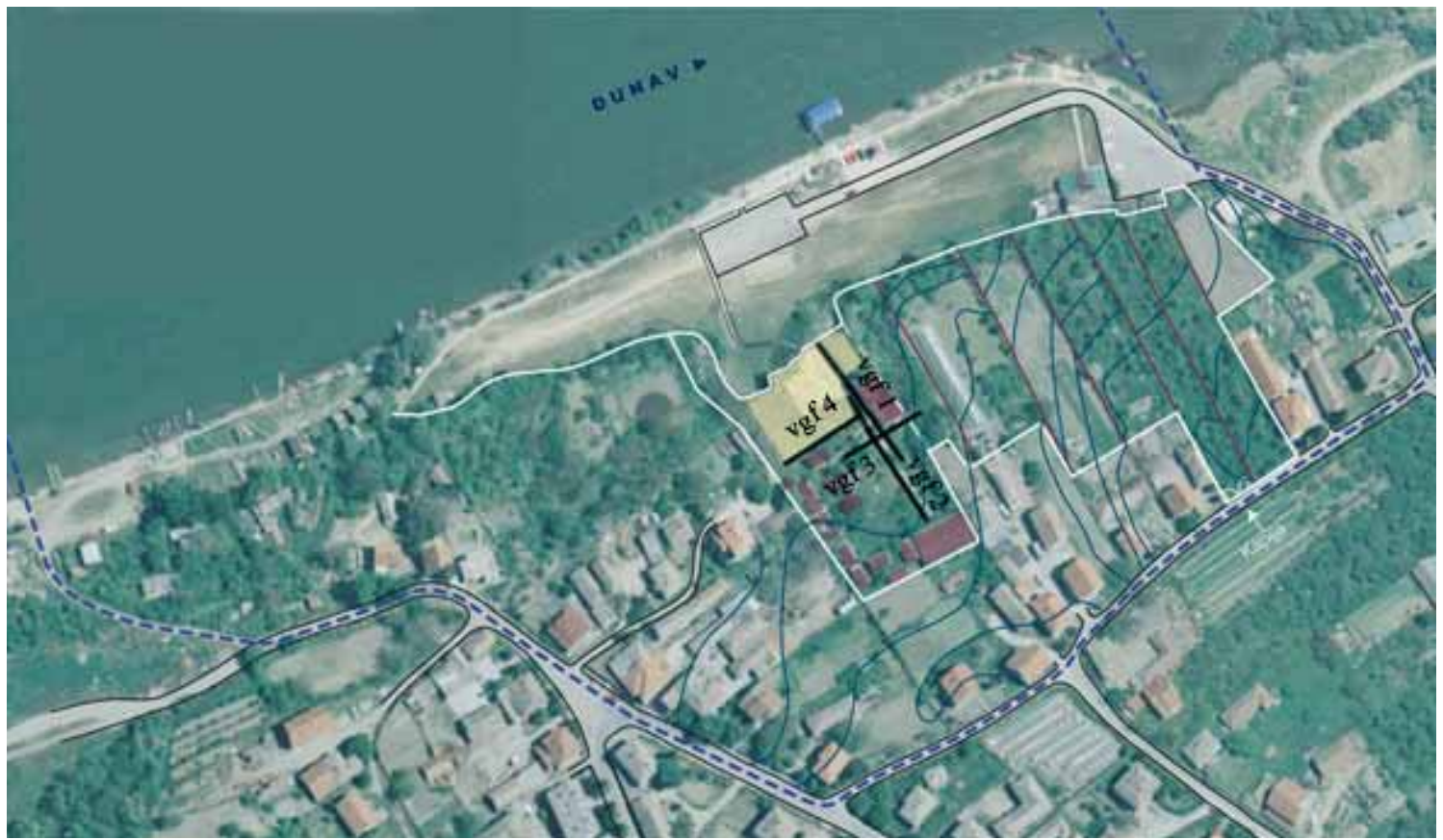

Slika 3. Orto fotografija lokaliteta sa pozicijom VGF profila 


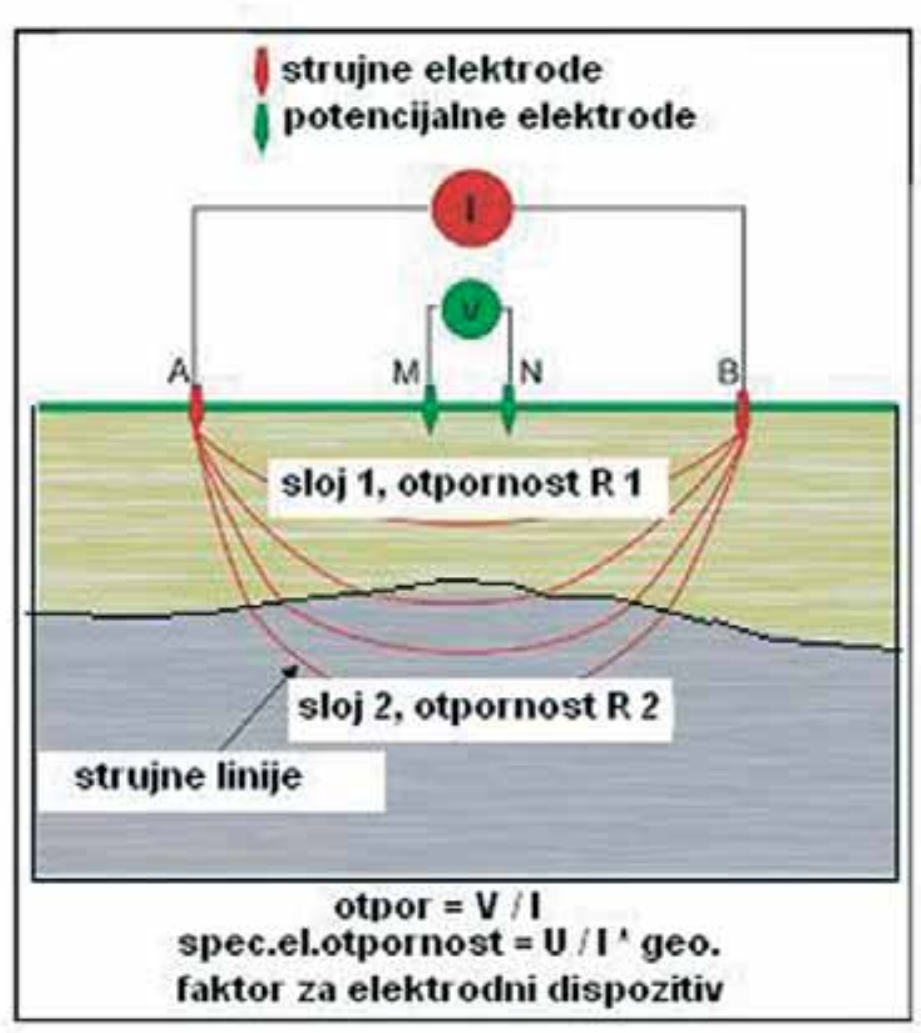

Четвороелектродни диспозитив
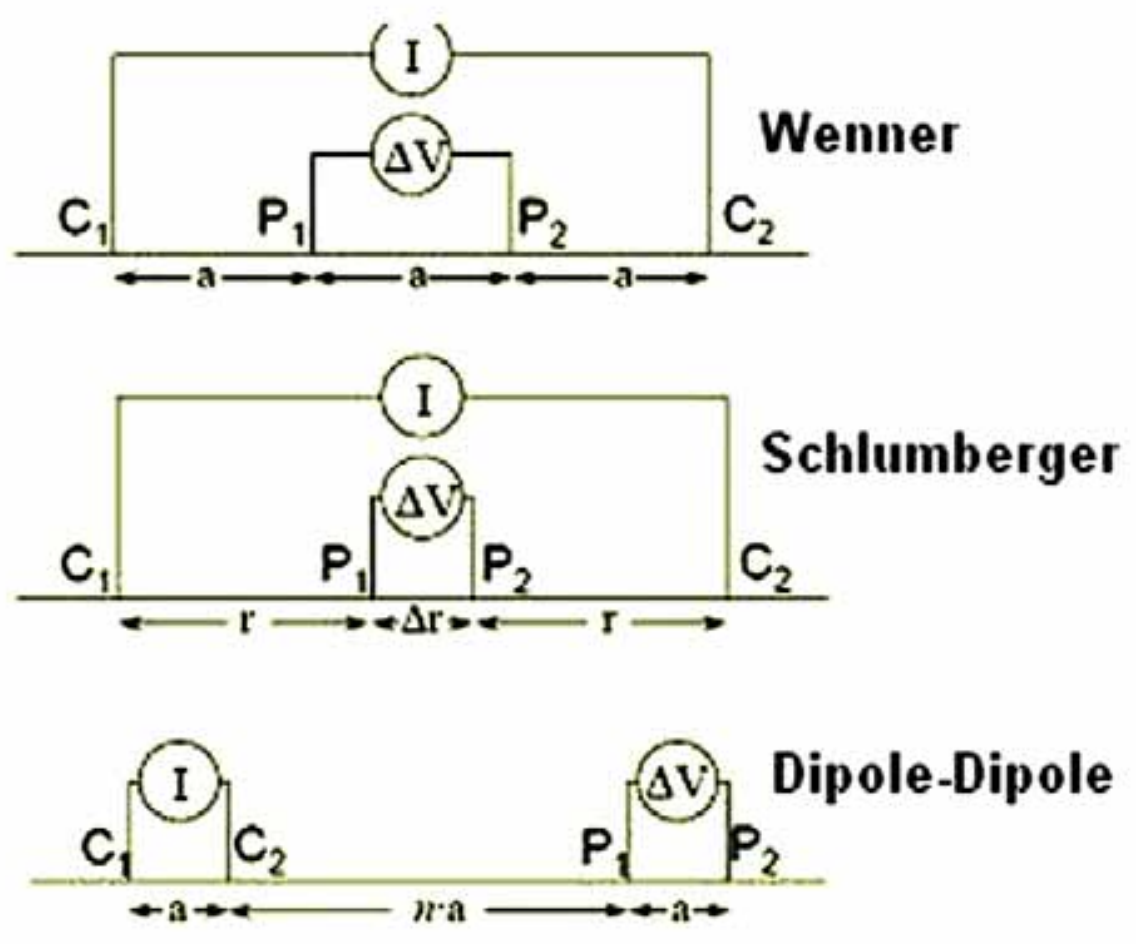


\begin{tabular}{|l|l|}
\hline GEOFIZIKA & ARHEOLOGIJA \\
\hline $\begin{array}{l}\text { Površinski snimak sa elektrodamajepravolinijski, } \\
\text { što vodi ka odstupanju u nižim slojevima }\end{array}$ & Površinske kote beleže pad terena ka istoku \\
\hline $\begin{array}{l}\text { Slojevi I i II su identifikovani u 4 sloja različitog } \\
\text { otpora kao i jedan ukop srednjovekovnog groba }\end{array}$ & $\begin{array}{l}\text { U slojevima I i II ne može se ustanoviti razlika, } \\
\text { koja je ustanovljena električnim otporom, ali je } \\
\text { potvrđen srednjovekovni ukop sa dva groba. }\end{array}$ \\
\hline $\begin{array}{l}\text { Slojevi III i IV se očitavaju kao različite } \\
\text { otpornosti. }\end{array}$ & $\begin{array}{l}\text { Slojevi III i IV su očigledno različiti, kako po } \\
\text { kvalitetu zemlje (sloj III je kompaktan, } \\
\text { a IV je rastresit sa puno pepela) tako i kulturno } \\
\text { - hronološki }\end{array}$ \\
\hline $\begin{array}{l}\text { Slojevi V i VI su identifikovani jednakim } \\
\text { rezistivitetom }\end{array}$ & $\begin{array}{l}\text { Sloj V i VI su sa arheološkog aspekta različiti, } \\
\text { obzirom da sloj V predstavlja šut od zidova, a VI } \\
\text { kompaktna podnica. }\end{array}$ \\
\hline
\end{tabular}

i VGF-4 su 25 m dugački, a dubinski zahvat je 2 $\mathrm{m}$. Merenje na kraćim profilima je imalo za cilj da se dobije maksimalna rezolucija ispitivanja ispod površine terena za potrebe dubinskog zahvata.

Presek VGF-4 je za sada jedini potvrđen arheološkim istražnim terenskim radovima. Presek VGF-4 obuhvata delove geodetske mreže arheološkog nalazišta Belo Brdo po blokovima B, C i D po V (petom) redu, odnosno linija geofizičkog profila je postavljena po mrežnom profilu $\mathrm{G}_{1}-\mathrm{G}_{7}$ a prostire se od $G_{1}$ do $G_{6}$. Profil je postavljen na višem delu terena, paralelno profilu na rastojanju od približno $1 \mathrm{~m}$ sa apsolutnom kotom $86,15 \mathrm{~m}$. Niži deo terena, prema Dunavu, ima kotu 85,65 m.

Posle geofizičkih snimanja južnog profila istraženog arheološkim iskopavanjima 1980 - 1984 godine, ${ }^{1}$ arheološka ekipa je očistila i zaglačala profil, koji se tokom petnaest godina urušio i odneo u proseku oko jedan metar u dubinu neistraženog dela kulturnih slojeva. Treba napomenuti, da je radi zaštite od daljeg urušavanja, profil zasečen pod uglom, što je donekle otežavalo sagledavanje precizne stratigrafske slike. Analizom geofizičkog snimka kao najinteresantnija učinila nam se zona oko elektrode br. 16. Odlučili smo da na tom mestu otvorimo kontrolnu sondu, koja je obuhvatila dva kvadrata odnosno lokuse 4 i 5 u Bloku VI, Kvadrat 2.

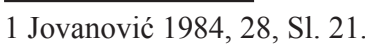

Kontrolna sonda je istraživana sa dvanaest (12) otkopnih slojeva, prosečne debljine $10 \mathrm{~cm}$. Na koti 85,20 m, u šestom otkopnom sloju, otkrivena su dva srednjovekovna groba, orijentacije severoistok-jugozapad, na samoj granici lokusa. Sačuvani grob pripada odrasloj individui, dok je dečiji grob naknadno ukopan. Ovaj grob se idealno poklapa sa stanjem dobijenim interpretacijom elektičnog otpora. Naime, na geofizičkom snimku vidi se pravilan upad u niži sloj svetlomrke zemlje neposredno iznad stambenog objekta.

Između kota $84,58 \mathrm{~m}$ i $84,76 \mathrm{~m}$ otkriven je ruševinski sloj zidova vinčanske kuće, kao i očuvana kompaktna podnica prekrivena tankim slojem pepela.

U osnovi probne sonde, na kotama izmedu $84,58 \mathrm{~m}$ i $84,76 \mathrm{~m}$, uočavaju se ostaci stambenog objekta koji je primećen i u profilu u dužini od 8 m (vidi sliku 6 ).

U profilu probne sonde može se uočiti šest različitih slojeva.

1. I sloj predstavlja površinski humus.

2. II sloj predstavljaju ukopi srednjovekovnih grobova. ${ }^{2}$ Donja granica ovog sloja ide-

2 Nekropola u Vinči traje od 8. do 18. v.n.e. Konstatovana je kao starosrpska nekropola još 1906. godine (Vasić 1906: str. 55-56). Prvi put je sistematski istraživana od 1978 do 1983. godine (Marjanović-Vujović1978, 129130; 1980,186-188; 1985, 105-106). Ukupan broj skeleta otkrivenih od 1911. do 1983. godine prelazi cifru od 1000. 


\section{VGF-1}

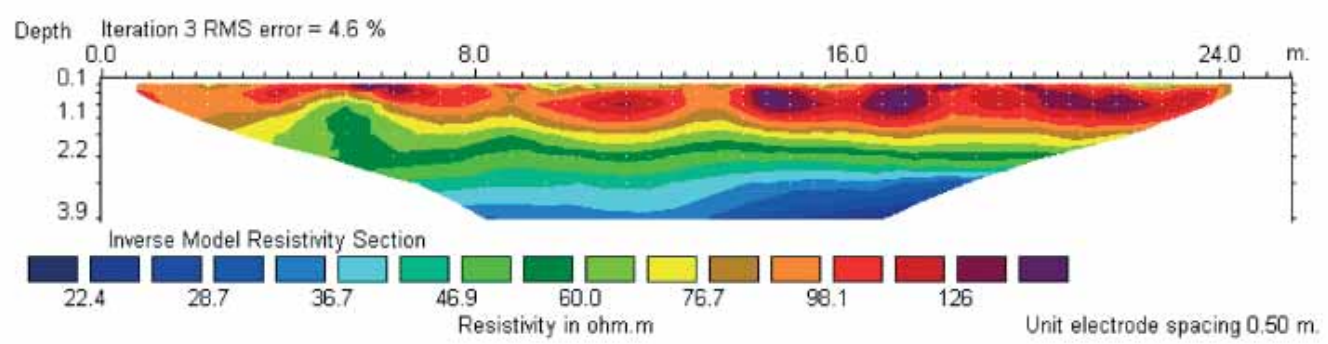

Inversion Completed

\section{VGF-2}

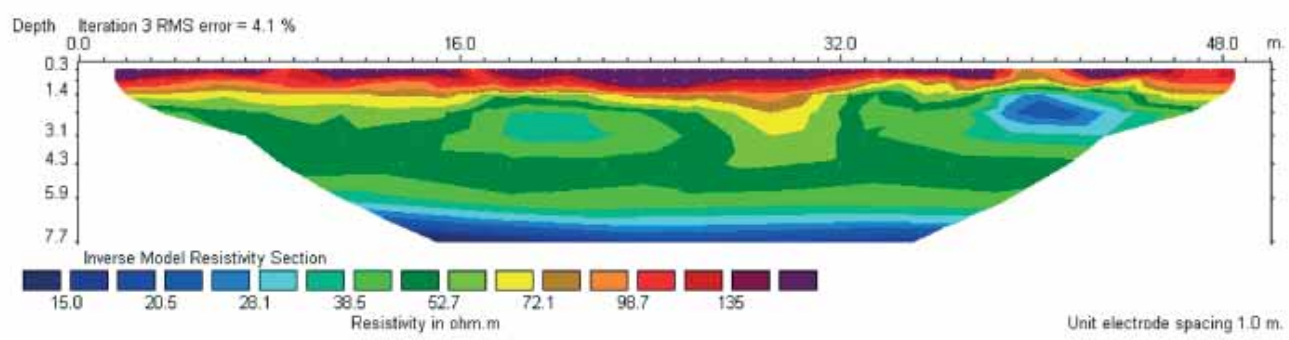

\section{VGF-3}

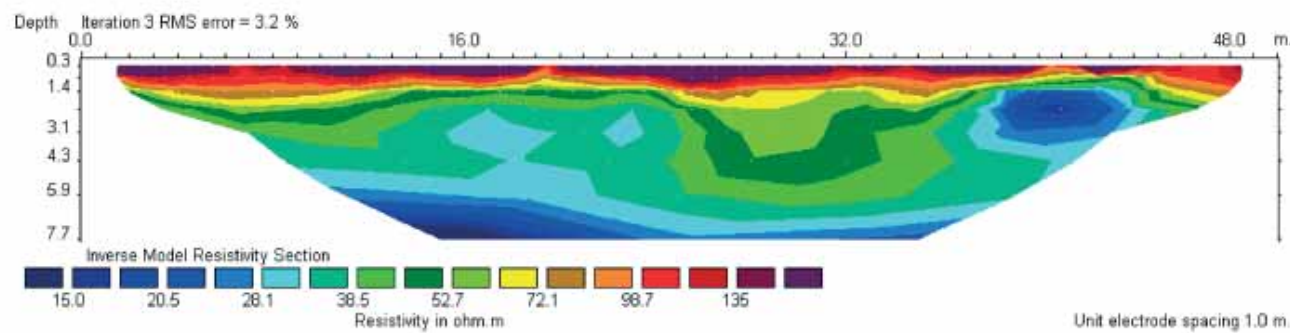

Slika 4. Izgled profila VGF - 1, 2, i 3

alno se poklapa sa geofizičkim snimkom. Istim snimkom nije ustanovljeno postojanje dva groba, što se može opravdati nedovoljnom rezolucijom, ali i činjenicom da je manji grob, verovatno deteta (otkrivene kosti pripadaju infantu), ukopan u raku starijeg groba odrasle osobe (Slika 8).

3. III sloj debljine $80 \mathrm{~cm}$ sastoji se od sve- tlomrke zemlje u kojoj od pokretnih arheoloških nalaza dominira materijal iz srednjeg bronzanog doba odnosno vatinske kulture ${ }^{3}$ (Slika 9 tabla sa keramikom).

3 (Tasić 1977, T. IV Abb. 2; Tasić 1984, T. XIV 1-4); (Bogdanović 1986, 37, sl. 37, 38, 40) 


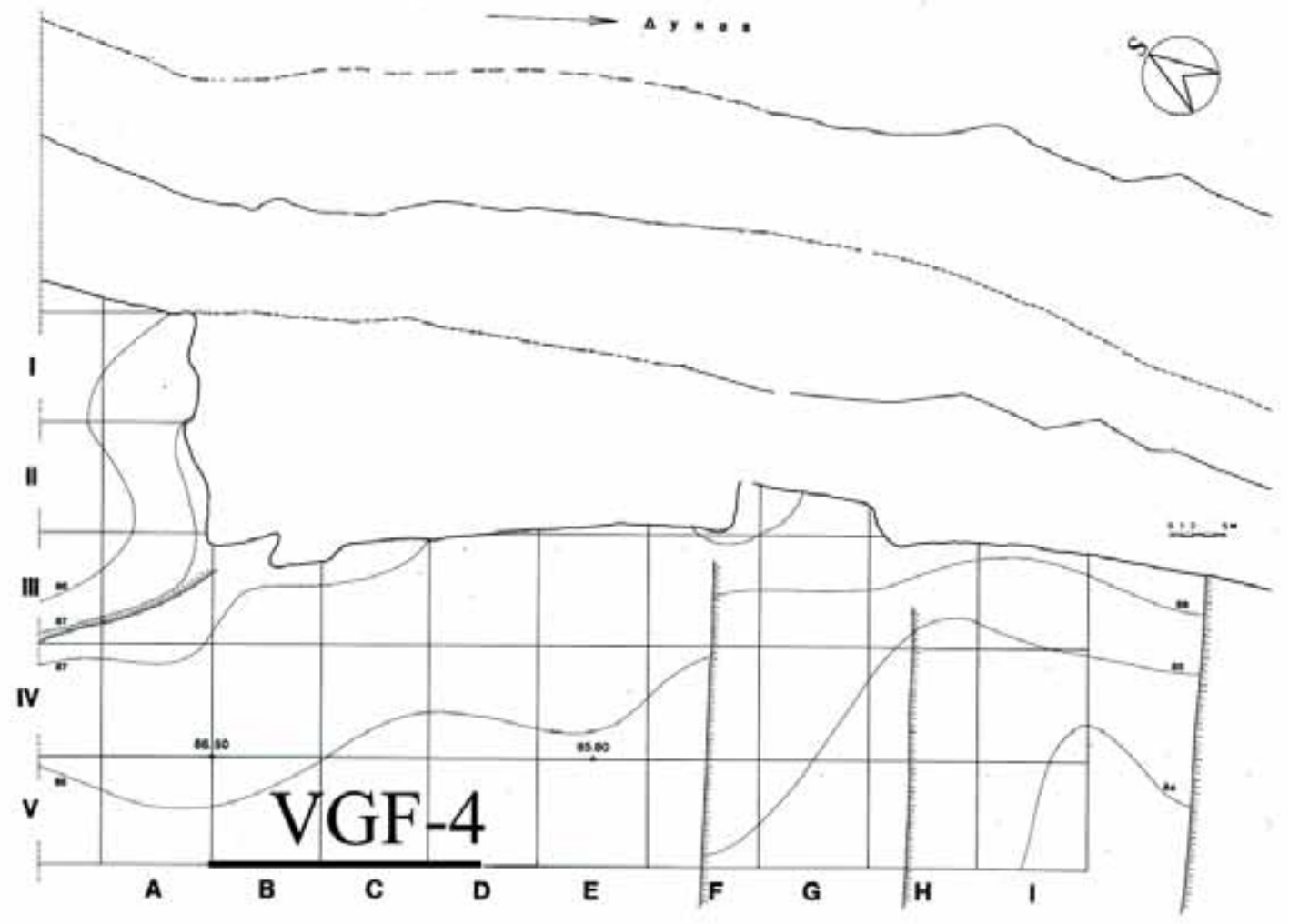

Vinca - Belo Brdo

geoelektricni presek $\mathrm{G} 4$

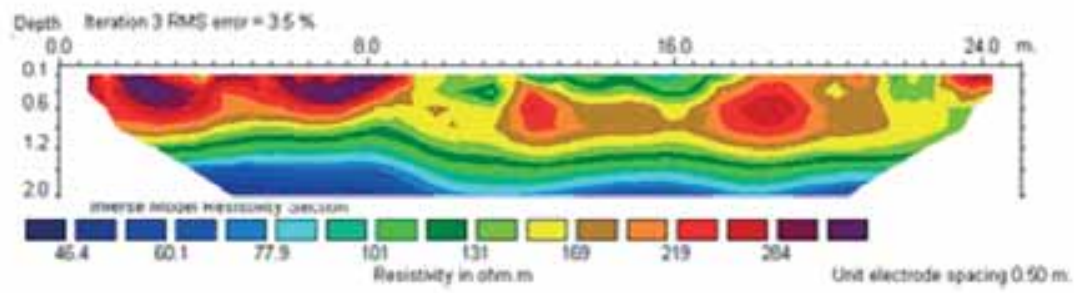

towersies tengleted

Slika 5. Izgled profila VGF-4

4. IV sloj predstavlja svetlomrka rastresita zemlja sa pepelom i gareži. Od pokretnog materijala $u$ ovom sloju pronađeni su fragmenti keramičkog posuđa iz bronzanog doba i eneolita ${ }^{4}$

4 Tasić 1995, 165;

Položaj vatinskog i badenskog kulturnog horizonta je stratigrafski lako odredljiv, ali se usred ukopavanja mlađeg u starije naselje ne može ustanoviti debljina svakog kulturnog sloja pojedinačno (Jevtić 1986, 135).
(Slika 9 tabla sa keramikom).

5. V i VI sloj predstavljaju ruševinski sloj zidova vinčanske kuće i kompaktne podnice, a keramički i koštani nalazi iz tog objekta hronološki pripadaju finalnoj fazi vinčanske kulture, VinčaPločnik IIa-IIb ${ }^{5}$ (Slika 9 tabla sa keramikom).

5 Garašanin 1979, 175-176, S1. 13, 28-29. 

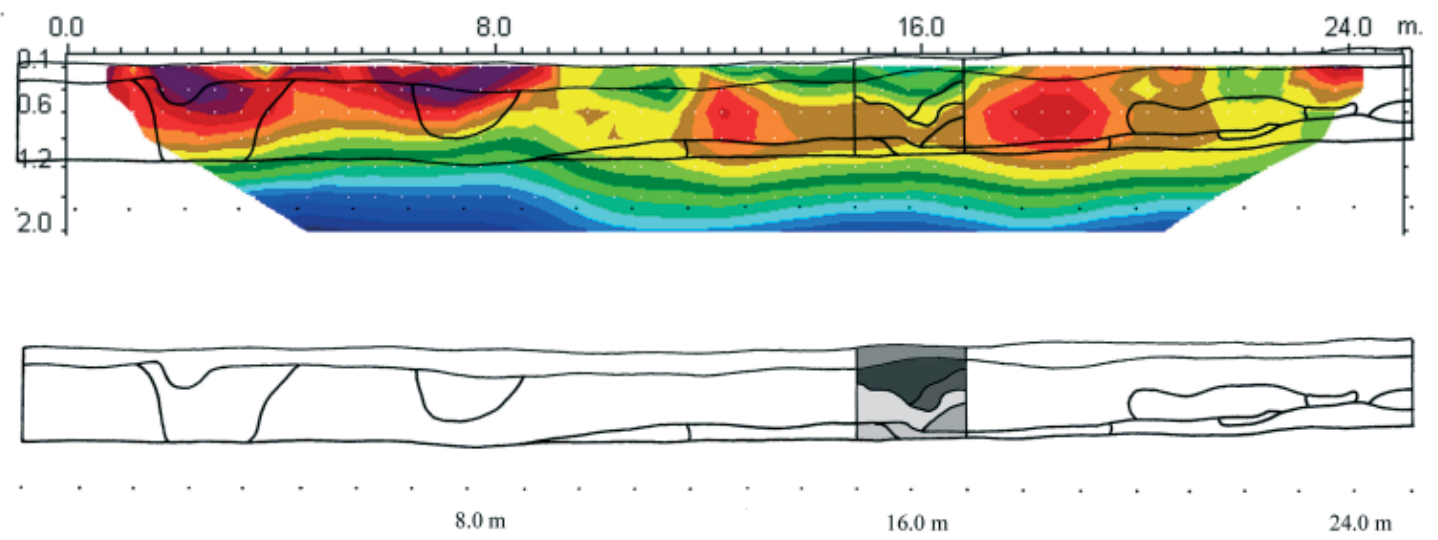

Slika 6. Preklopljeni geoelektrični i arheološki profil

\section{ZAKLJUČAK}

Posle izvršene komparativne analize geoskeniranja i arheološkog snimanja profila, možemo zaključiti da se oba metoda u dobroj meri preklapaju.

Uporedni slojevi dobijeni merenjem električnog rezistiviteta i arheološkom metodologijom prikazani su u tabeli.

Ovo interdisciplinarno istraživanje je sigurno korak u pravom smeru koji će nam u doglednoj budućnosti omogućiti da metodom merenja specifičnog električnog otpora, ne samo pronalazimo objekte, već i da planiramo strategiju iskopavanja.

Površinski snimak sa elektrodama je pravolinijski, što vodi ka odstupanju u nižim slojevima. Ova greška se može prevazići korišćenjem dodatnog softvera koji je u planu.

Kao što je to u slojevima V i VI potvrđeno arheološkim sredstvima, metodologija geoskeniranja u primenjenoj rezoluciji ne može da razlikuje kompaktni od rastresitog kućnog lepa, ali ga ipak jasno odvaja od okolne zemlje.

Uspeli smo da izdvojimo i atribuiramo određene strukture i vrste zemljišta, kao što su ukopi i, što je naročito važno u metodologiji praistorijskih istraživanja, strukture od pečene zemlje. Ova atribucija će nam omogućiti da prilikom sistematskog snimanja Belog Brda u Vinči, ili na bilo kom arheološkom nalazištu, bez iskopavanja dođemo do odgovora na pitanja o strukturi naselja, postojanju ili nepostojanju sistema odbrane $u$ pojedinim fazama i sl.

S obzirom da je savremena arheološka metodologija veoma spora, s obzirom da se traga za detaljima koji mogu da pomognu prilikom interpretacije, geoskeniranje i ostale metode detekcije, mogu da nam pruže nezamenjive podatke prilikom rekonstrukcije celine naselja ili nekropola.

\section{BIBLIOGRAFIJA:}

\section{Богдановић 1986}

Богдановић М., Љуљаци насеље протоватинске и ватинске културе, Крагујевац 1986.

\section{Васић 1906}

Васић М., Старосрпска налазишта у Србији, Старинар 1, Београд 1906, 55-56.

\section{Garašanin 1979}

Garašanin M., Centralnobalkanska zona, Vinčanska grupa, Praistorija jugoslovenskih zemlja 2, Sarajevo 1979, 144-12.

\section{Јевтић 1986}

Јевтић М., Гробови бакарног доба из Винче, Старинар 37, Београд 1986, 135-144.

\section{Јовановић 1984}

Јовановић Б., Насеља винчанске културе, Стратиграфија, Винча у праисторији и средњем веку, каталог изложбе у галерији САНУ, Београд 1984, 23-34.

\section{Marjanović-Vujović 1978}

Marjanović-Vujović G., Vinča-Beli Breg, Brdo, srednjovekovna nekropola, Arheološki pregled 20, Beograd 129-130. 
Marjanović-Vujović 1980

Marjanović-Vujović G., Beli BregBelo brdo, Vinča srednjovekovna nekropola, Arheološki pregled 21, Beograd 1980, 186-188.

\section{Марјановић-Вујовић 1985}

Марјановић-Вујовић Г., Прилог проучавању историјата истраживања средњовековних некропола у Србији, Старинар 36, Београд 1985, 105-114.

Tasić 1977

Tasić N., Neue funde der Vatiner kultur aus den Jugoslawischem Donauraum, Archaeologia Iugoslavica Vol. 18., Beograd 1977, 17-25.

Tasić 1984.

Tasić N., Kulturen der Frühbronzezeit das Karpatenbeckens und Nordbalkans. Beograd 1984.

Tasić 1995

Tasić N., Eneolithic cultures of central and west Balkans, Beograd 1995.

\section{COMPARATIVE ARCHAEOLOGICAL AND GEOPHYSICAL RESEARCH ON SITE VINČA BELO - BRDO USING METHOD OF GEOELECTRIC SCANNING}

In autumn 1998 archaeological research on the site Vinča-Belo Brdo was renewed, just at the 90th anniversary of the first excavations conducted by Miloje M. Vasić. One of the aims of the new research was introduction of multi-disciplinary work and adjustment of classical archaeological research to new accomplishments of other scientific fields. Our wish is to examine some of the objects as good as possible, by researching details which were impossible to examine in the time of Vasić's excavations and in the same time trying to secure the best context possible to small finds. During the new research, numerous methodologies were introduced. One of them was technique of measuring electric resistivity, to which this paper is dedicated.

Application of measuring electric resistivity by methods described below is new in our archaeology. This is why a need occurred to conduct parallel geo-physical and archaeological research, in order to check the attribution of the measures gained by examining electric resistivity.

Quick technological development and introduction of computers in geo-physics and archaeology made it possible to represent measuring in two or three dimensions. This represents an excellent base for a serious research and efficient cooperation of geo-physicists with other scientists. Such interpretations are of the utmost importance to archaeologists, since they show contents of the sub-soil structures in a clear and easily understandable way.

The measured profiles were fit into the archaeological net and placed in such a way that it was possible to check the preciseness of the method and get the retroactive information in classical archaeological methods. In such a way, an "attribution" of certain kinds of soil in relationship to the values of electric resistivity gained by measuring was made.

From 1999 to 2001 pilot geo-physical research was undertaken by applying the method of vertical geo-electrical sounding. During 2000, four profiles were done with methods of geo-electric scanning or geo-electric tomography.

By now, the cross-section VGF-4 is the only one that was confirmed by archaeological excavation. This cross-section includes parts of the net within the blocks B, C and D in the 5th row, i.e. the line of the geo-physical profile was placed corresponding to the net-profile g1-g7 a, that spreads from $\mathrm{g} 1$ to $\mathrm{g} 6$. The profile was set at the upper terrain part, parallel with the profile set approximately at 1 meter distance, with the peak elevation $85,65 \mathrm{~m}$. The lower terrain part, towards the Danube, is at the peak elevation $85,65 \mathrm{~m}$. After the comparative analysis of geo-scanning and archaeological examination of the profile, we can conclude that the results of both methods mostly match. Just like it was confirmed with archaeological research in the layers V and VI, the method of geo-scanning does not tell the difference between compact and loose wattle wall, but it still differs it clearly from the surrounding soil.

This is understandable, because by scanning, one can recognize and separates different materials according to their physical parameter of specific electric resistivity, and the wattle wall, compact or not, possesses similar electric resistivity.

Geo-physic measuring, undertaken in sec- 
tor II of the archaeological site Belo Brdo in Vinča showed that the method of geo-sounding is very suitable for application within archaeology. In such way, it is possible to determine the spreading of layers on a site and the existence of sub-soil structures. By applying such methods, creating of the excavation strategy is made easier for archaeologists, which brings us closer to the idea of a "non-invading" archaeological research. In such a way, parts of the site get examined but still remain preserved for future generations of archaeologists. Translated by M. Tapavički-Ilić

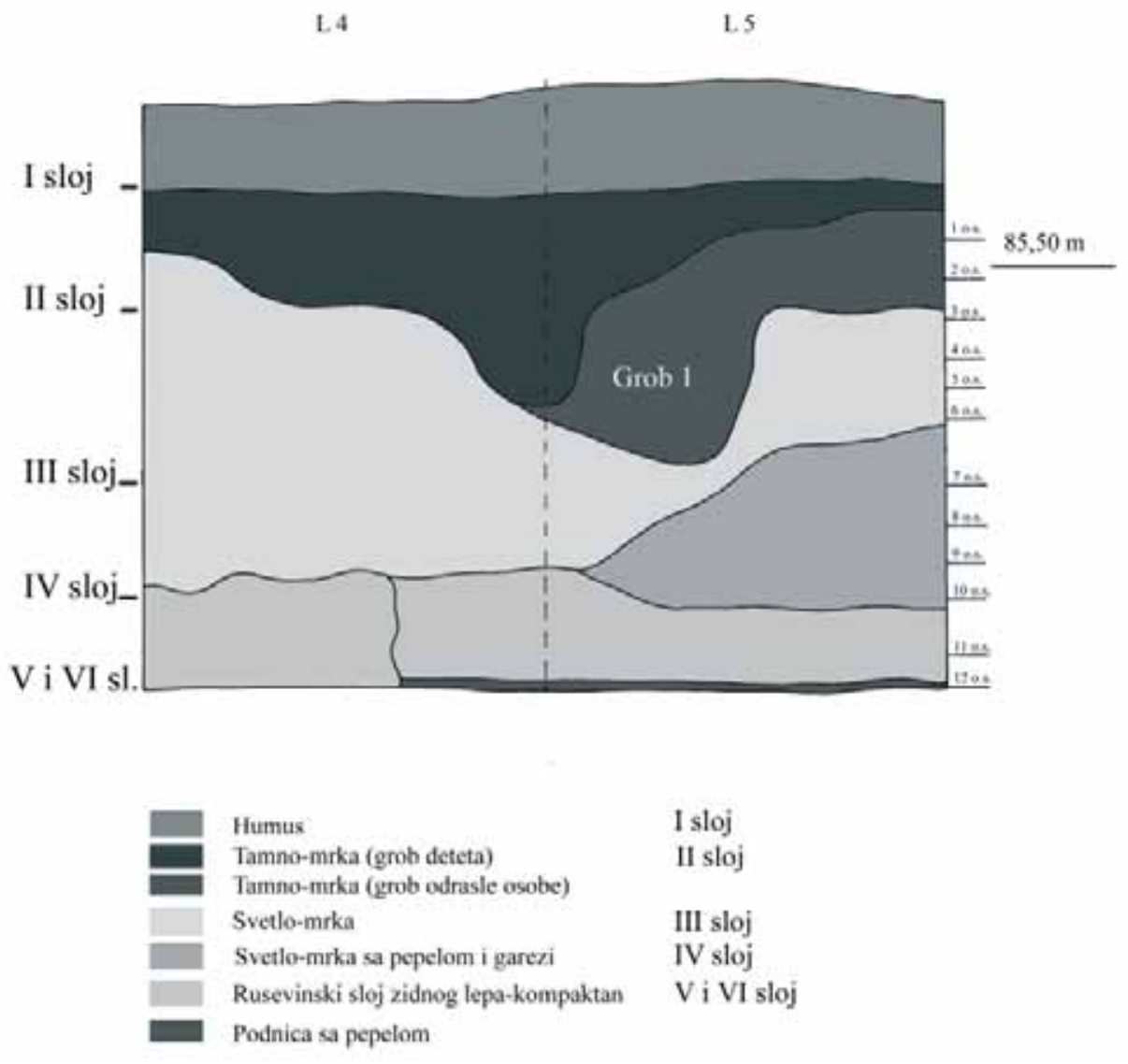

Sl. 7 Profil sa lokusima 4 i 5

L 4

L 5

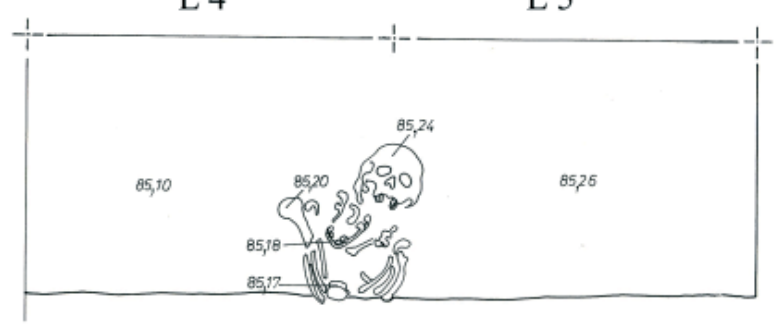

Grob 1

Sl. 8 Grob 1/2001 u lokusima 4 i 5 

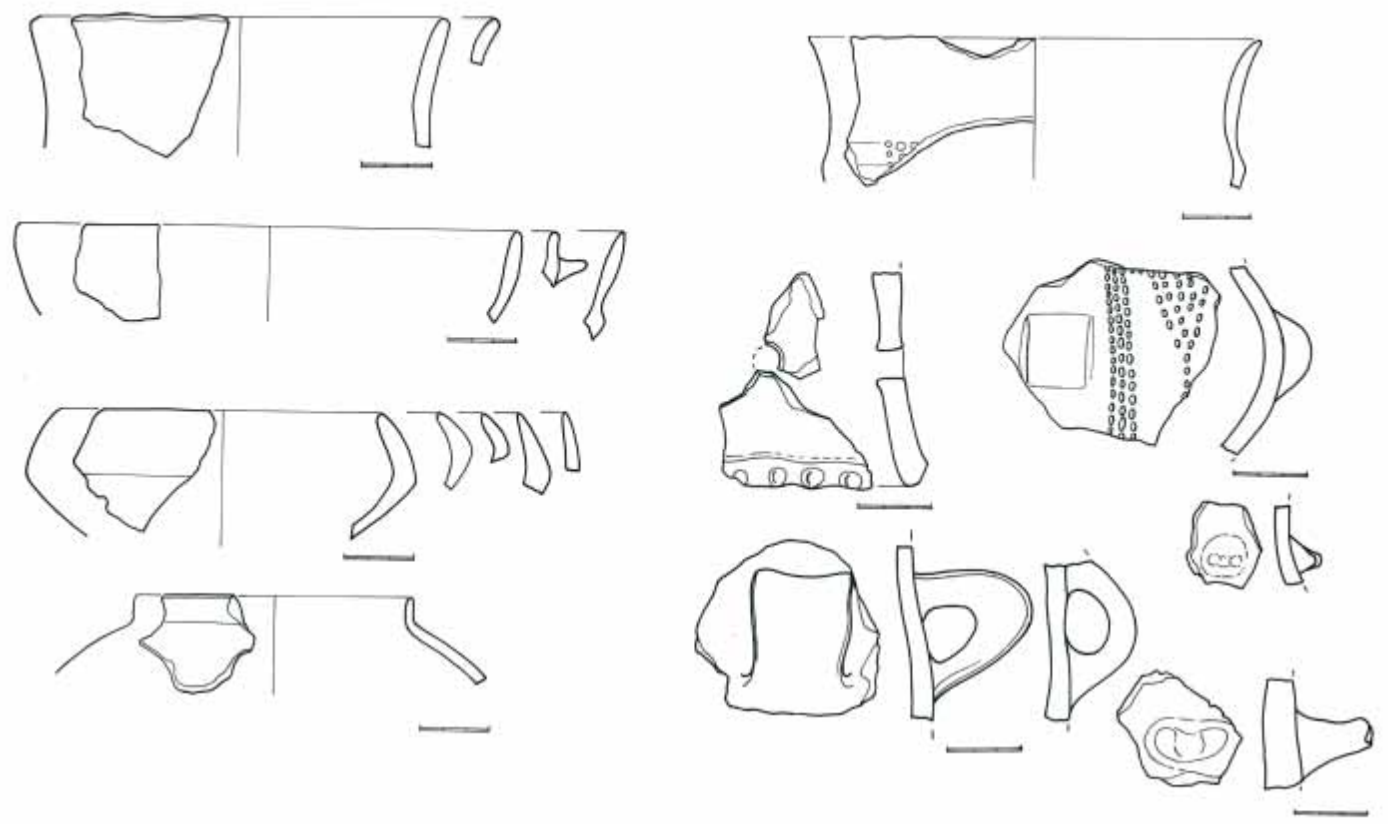

Ruševinski sloj iznad podnice V i VI sloj

Svetlo - mrka sa pepelom i gareži IV sloj
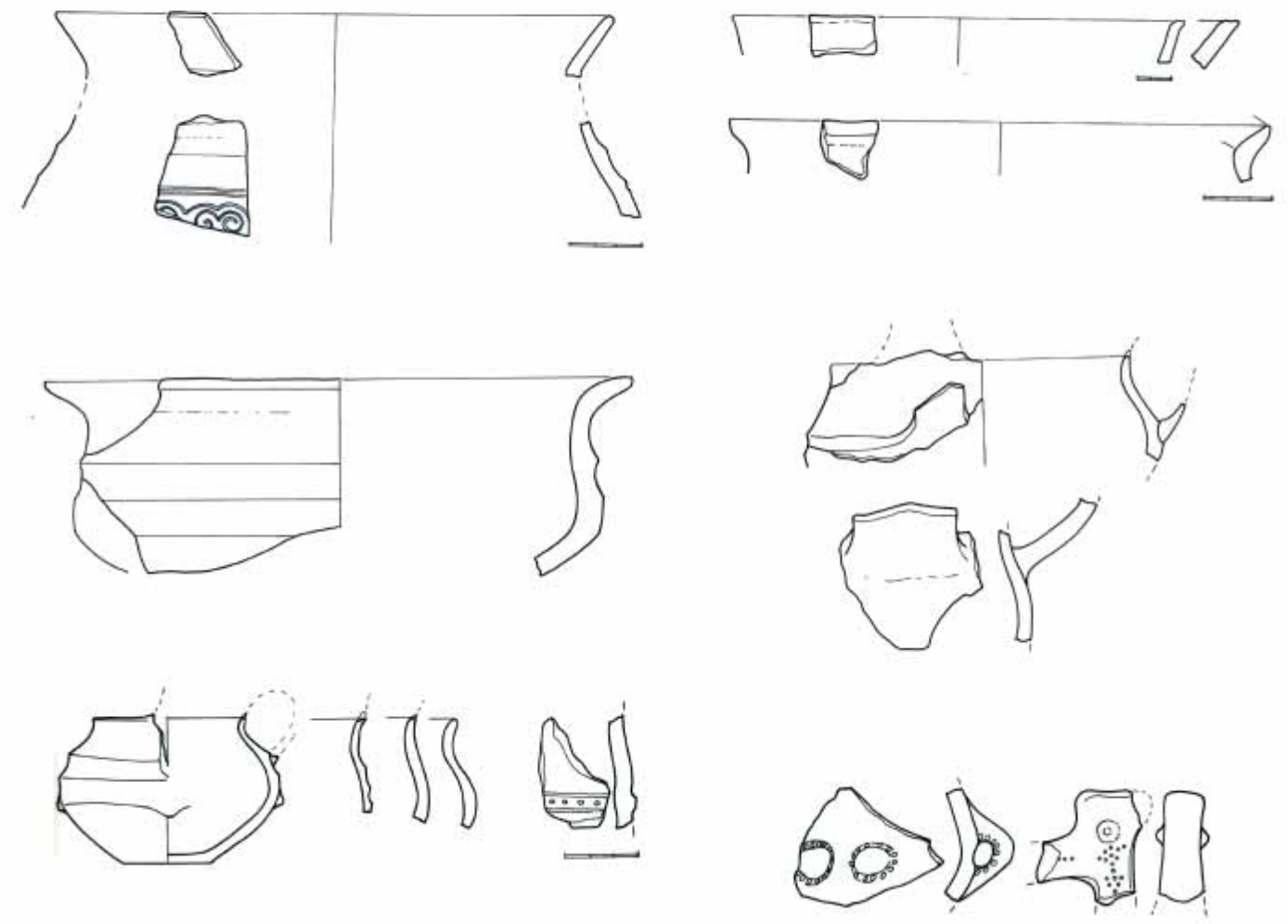

Svetlo -mrka kompaktna III sloj

Slika 9. Keramički materijal 